\title{
The growth hormone/prolactin gene family in ruminant placentae
}

\author{
R. V. Anthony, R. Liang, E. P. Kayl and S. L. Pratt* \\ Animal Reproduction and Biotechnology Laboratory, Department of Physiology, \\ Colorado State University, Fort Collins, CO 80523, LSA
}

\begin{abstract}
Ruminant placentae produce at least two distinct subclasses of the growth hormone/prolactin gene family, the placental lactogens and prolactin-related proteins. Placental lactogens have been purified from cattle, goat and sheep placentae, and the amino acid sequences of bovine and ovine placental lactogen are known. Bovine and ovine placental lactogens are structurally more similar to prolactin than they are to growth hormone. In addition, six unique mRNAs have been described in cattle that encode prolactin-related proteins that are structurally distinct from ruminant placental lactogens. All characterized ruminant placental lactogens and prolactin-related proteins are products of chorionic binucleate cells, but specific biological functions of these placental hormones have not been elucidated. Ovine placental lactogen may modify maternal and fetal intermediary metabolism to provide energy substrates to the fetus. Bovine placental lactogen has been implicated as a luteotropic agent, and is also capable of stimulating mammogenesis and lactogenesis. No ruminant placental lactogen receptor has been structurally characterized, although they are presumed to be similar to either the growth hormone or prolactin receptor. Available technologies will allow many of the questions regarding the regulation, mechanism of action and function of these placental hormones to be addressed.
\end{abstract}

\section{Introduction}

In eutherian mammals, the placenta is responsible for directly mediating or modulating the maternal environment required for maintenance of normal fetal growth and development. The placenta is the site of nutrient and waste transfer between the mother and fetus, serves as a barrier against pathogens and the maternal immune system, and functions as an active endocrine organ. Among the hormones synthesized and secreted by the placenta are members of the growth hormone $(\mathrm{GH}) /$ prolactin gene family, including the placental lactogens (PLs), prolactin-related proteins (PRPs) and placental growth hormone (GH.V; Roberts and Anthony, 1994). Most species that have been examined secrete one or more of the placental members of this family; horses, pigs and rabbits are exceptions. Primates secrete both PL and GH-V, whereas non-primate speciés produce one or more PLs and, at least in rodents and ruminants, one or more PRPs.

Although ruminant PLs have been known to exist for approximately 20 years, and the PLs expressed by bovine and ovine placentae were amongst the earliest purified to homogeneity, we still cannot draw firm conclusions about their regulation, their exact mechanism of action nor their specific biological functions. Use of recombinant DNA methods led to the discovery of mRNA encoding PRPs within the

* Present address: Department of Molecular and Cellular Physiology, University of Cincinnati, 231 Bethesda Ave, Cincinnati, $\mathrm{OH}$ 45267-0576, USA. 


\begin{tabular}{|c|c|c|c|c|c|c|c|c|c|c|}
\hline & opl & DPL & GPRP.I & GPRP.\|I & GPRP. III & DPRP. IV & DPRP.Y & GPBP.VI & 6PRL & 6GH \\
\hline OPL & & 65.7 & 32.3 & 32.3 & 31.8 & 32.3 & 31.8 & 33.8 & 47.5 & 24.2 \\
\hline BPL. & 83.8 & & 30.0 & 29.5 & 31.5 & 29.5 & 30.0 & 32.5 & 50.2 & 23.7 \\
\hline APPP. & 63.6 & 62.4 & & 75.2 & 59.9 & 75.2 & 51.0 & 53.7 & 44.7 & 21.0 \\
\hline GPAPA- & 59.2 & 69.0 & 86.2 & & 56.9 & 99.5 & 4.1 & 51.2 & 43.7 & 24.2 \\
\hline DPAP-III & 59.7 & 628 & 800 & 78.2 & & 56.9 & 56.9 & 672 & 43.2 & 20.2 \\
\hline GPRP.-IV & 61.0 & 81.2 & 89.5 & 95.8 & 78.4 & & 4.1 & 51.2 & 43.7 & 24.2 \\
\hline GPRP. Y & 624 & 69.2 & 768 & 71.5 & 77.6 & 74.9 & & 56.2 & 42.2 & 18.4 \\
\hline GPRE:VI & 62.2 & 62.2 & 78.8 & 75.9 & 83.8 & 78.4 & 79.6 & & 45.2 & 17.9 \\
\hline bPAL & 67.8 & 69.9 & 60.5 & 88.1 & 88.1 & 88.1 & 68.7 & 68.1 & & 27.9 \\
\hline 6GH & 53.5 & 52.3 & 58.7 & 59.1 & 50.0 & 55.0 & 53.11 & 52.3 & 52.8 & \\
\hline
\end{tabular}

Fig. 1. Nucleotide and amino acid sequence identity among the members of the ruminant growth hormone/prolactin gene family. The sequence comparisons were generated using NALIGN (nucleotide comparisons) and PALGN (amino acid comparisons) programs with PC/GENE (IntelliGenetics, Inc., Mountain View, CA). Only the protein coding regions were used for the nucleotide sequence comparisons, and the mature (minus the leader peptide) amino acid sequences were used in the amino acid comparisons. ( $\square$ ) percentage nucleotide sequence identity; $(\square)$ percentage amino acid sequence identity. PL: placental lactogen; PRP: prolactin-related proteins; PRL: prolactin; $\mathrm{GH}$ : growth hormone.

bovine placenta (Schuler et al., 1991). However, their existence in other ruminant placentae has yet to be reported, and we know even less about the regulation and function of the ruminant PRPs than we do about the PLs. This review will focus on our current knowledge of structure, regulation, mechanism of action and proposed functions of the ruminant PLs and PRPs.

\section{Structure and Regulation of Ruminant Placental Lactogens and Prolactin-related Proteins}

\section{Primary structure}

Placental lactogens have been purified from the placentae of cattle (Murthy et al., 1982), goats (Currie et al., 1990) and sheep (Warren et al., 1990b), and the primary structures of bovine PL (bPL: Schuler et al., 1988) and ovine PL (oPL: Warren et al., 1990b) have been determined by a combination of amino acid and CDNA sequencing. Both bPL and oPL (Fig. 1) are structurally more similar to prolactin than they are to GH in both nucleotide and amino acid sequence. Although bPL and oPL are more similar to each other than they are to other members of this gene family, the interspecific divergence in the primary sequence of the ruminant PLs is greater than the interspecific divergence of either prolactin or GH. Analysis of ruminant PL sequence similarities (Wallis, 1993) indicated that the rate of nonsynonymous substitution was greater than the rate of synonymous substitution, leading to the suggestion that the more rapid rate of evolution between bPL and oPL resulted from adaptive rather than from neutral mutations.

Ovine PL is a nonglycosylated polypeptide with an apparent $M_{r}$ of 22000 (Warren et al., 1990a), which appears to undergo little post-translational processing other than removal of a 38 amino acid leader peptide (Warren et al., 1990b). Caprine PL (Currie et al., 1990) has similar properties $\left(M_{\mathrm{r}} \approx 22500 ; \mathrm{pl} \approx 8.35\right)$ to oPL (Warren et al.x 1990a), and although not proven, it is unlikely that caprine PL is glycosylated. In contrast, bPL is secreted as multiple isoforms (32-34000 $M_{r}$; Murthy et al., 1982) that contain both Asn-linked and O-linked oligosaccharide chains (Byatt et al., 1990), 
Removal of the Asn-linked oligosaccharides increases (1.2-2.3 fold) the binding of bPL to the GH receptor but not to the $\mathrm{Nb2}$ cell prolactin receptor (Byatt ef al, 1990), whereas removal of O-linked oligosaccharides has no effect on receptor binding. None of the ruminant PLs has been crystallized, so it remains unclear whether the differences in their primary sequence and occurrence of glycosylation result in overall structural divergence sufficiently significant to alter function.

In cattle, the placenta can produce at least six prolactin-related proteins (Schuler et al., 1991) that are structurally distinct from PL (Fig. 1). All bovine prolactin-related proteins (bPRPs) were identified by screening placental CDNA libraries, and are predicted to be glycoproteins containing Asn-linked oligosaccharide chains. The six bPRPs, as a group, are structurally more similar to each other than they are to $\mathrm{PL}$, prolactin or $\mathrm{GH}$, but there is considerable diversity among the bPRPs in their primary amino acid sequences (Fig. 1). Translation of bPRP-I has been demonstrated (Zieler et al., 1990), and it exists as two $M_{r}$ forms ( $\approx 34000$ and 35000 ) each containing Asn-linked oligosaccharide chains. Identification of prolactin-related proteins or their mRNA in other ruminant placentae has not been reported. However, we (E. P. Kayl and R. V. Anthony, unpublished) have preliminary evidence from reverse transcriptase-polymerase chain reaction of ovine placental mRNA that there are at least three analogous prolactin-related proteins in sheep.

\section{Gene structure and expression}

Structural genes encoding bPL, bPRP-1 and oPL have been isolated and characterized (Ebbitt et al, 1989; Kessler and Schuler, 1991; Liang and Anthony, 1993). All three genes comprise five exons and four introns, and the exons of each gene span 10-12 kilobases (kb) of DNA. At least in cattle, all placental members of this gene family are linked on chromosome 23 with the bovine PRL gene (Dietz et al., 1992). Consensus sequences for activator protein- 1 and -2 response elements reside within the immediate $5^{t}$ flanking regions of the bPL and oPL genes, which may be involved in basal promotor activity. As yet, neither these response elements nor other putative response elements identified by sequence analysis have been tested for functionality. The lack of ruminant-derived chorionic cell lines has hindered a thorough characterization of the transcriptional control of these genes. Gene copy number was not determined for the bPL or bPRP-I genes, but we have evidence that oPL is encoded by a single copy gene (R. Liang and R. V. Anthony, unpublished). However, evidence for differential splicing of the bPL transcript and allelic variants of the bPL gene has been reported by Yamakawa et al. (1990) and Kessler and Schuler (1991).

Bovine PL, bPRP-I and oPL are products of chorionic binucleate cells (Milosavljevic et al., 1989; Kappes et al., 1992; Fig. 2), which deliver their products to the maternal circulation by migrating to and fusing with the feto-maternal syncytium (Wooding, 1992). Expression of bPL and bPRP-I mRNA has been detected as early as day 17 of gestation (Kessler et al., 1991), and their expression appears to increase at least until day 140 of gestation. Expression of oPL mRNA increases from day 60 to day 120 of gestation (Kappes et al., 1992) when it appears to reach a plateau (Fig. 3). However, if the concentration of oPL mRNA is expressed on a per cell basis, expression does not change from day 60 to day 135 of gestation (Kappes et al, 1992). The percentage of chorionic epithelial cells that are binucleate remains constant during this time (Wooding, 1982), but as gestation progresses there is an increase in the total amount of chorionic epithelium within the placentome. Taken together, these results suggest that the increase with gestational age in concentrations of oPL mRNA was a result of increased total chorionic epithelial cells, including a proportional increase in total chorionic binucleate cells (Kappes et al., 1992). This raises the question of whether or not the primary regulator of oPL gene transcription is the progression of differentiation of chorionic primary cells into binucleate cells (i.e. constitutive expression). Until a system is developed to examine binucleate cell differentiation, this hypothesis will be difficult to test thoroughly.

\section{Secretion}

The interspecific divergence of ruminant PLs is not only observed with their primary amino acid sequences, but is also apparent in the amount of PL that reaches the maternal circulation. Ovine PL 
hypoglycaemía in either the mother or fetus (Brinsmead et al., 1981), which leaves the identity of the stimulus in question.

\section{Mechanism of Action of Ruminant Placental Lactogens}

\section{Cattle}

An issue that remains to be resolved is the mechanism of action by which ruminant PLs and PRPs exert their effects. More specifically, the question relates to whether there are unique PL or PRP receptors. Specific binding sites for bPL have been identified in endometrium (Kessler et al., 1991) and luteal tissue (Lucy et al, 1994) which have little affinity for bGH or bPRL. However, Staten et al. (I993) demonstrated that bPL binds the bovine growth hormone $(\mathrm{bGH})$ receptor in a 1:I stoichiometry rather than the 1:2 stoichiometry observed with bGH. In addition, a monoclonal antibody that competes with bGH for its binding site (Staten et al., 1993) does not compete with bPL binding to the bGH receptor or the recombinant bGH binding protein (bGHBP; extracellular domain of bGH receptor). Scott et al, (1992) demonstrated that bovine endometrium, corpus luteum and fetal liver all contain mRNA encoding the bGH receptor, and Lucy et al. (1993) provided evidence that the corpus luteum contains protein that is immunoreactive with antisera raised against the bGHBP. These data raise the possibility that $\mathrm{bPL}$ is acting through the bGH receptor by binding to a different site on the receptor. However, if this is true, the question must be raised as to why specific bGH binding cannot be demonstrated with endometrial or luteal microsomal membranes (Kessler et al., I991; Lucy et al., 1994). Lucy et al. (I993) observed two types of bGH receptor mRNA (4.4 and $4.7 \mathrm{~kb}$ ) from luteal tissue and a single type (4.4 kb) from liver. It is possible that the $4.7 \mathrm{~kb}$ transcript encodes a variant form of the bGH receptor that retains its binding affinity for bPL, but has significantly reduced affinity for bGH owing to conformational changes in the receptor.

Scott et al. (1992) reported that the bovine prolactin (bPRL) receptor is also expressed by the corpus luteum, endometrium and fetal liver. When the bPRL receptor was expressed in COS cells (Scott $e t a l$, I992), bPL and bPRL exhibited similar affinity for this receptor ( 0.20 versus 0.31 nmol ${ }^{-1}$; respectively), raising the possibility that in some tissues, bPL may be exerting its action through the bPRL receptor, Recent evidence from our laboratory (Anthony et al., 1994) demonstrates that there are two forms of ovine prolactin (oPRL) receptor mRNA in adult ovary and fetal liver. One oPRL receptor mRNA (oPRLR-1) is predicted to encode a receptor analogous to the reported bPRL receptor (Scott et al., 1992; Fig. 4), and one encodes a truncated form of the oPRL receptor (oPRLR-2). Termination of translation of oPRLR-2 (Anthony et al., 1994) is predicted to occur between Homology box 1 and 2 (DaSilva el al. 1994), at a site analogous to that of the short-form prolactin receptors expressed in mice (Davis and Linzer, 1989) and rats (Boutin et al, 1988). Truncation of the rat PRL receptor between Homology box 1 and 2 disrupts the phosphorylation of and the association between JAK 2 tyrosine kinase and the receptor (DaSilva et al., 1994), although the affinity of prolactin is equivalent to that exhibited by the full-length receptor. If an analogous 'short' prolactin receptor is expressed in ruminants, it may bind PL or bPRP, possibly acting through a signal transducer other than JAK2.

\section{Sheep}

Binding of oPL has been examined most extensively with maternal and fetal liver microsomes (Freemark et al., 1986; Freemark and Comer, 1989), Ovine PL expresses specific high-affinity binding $\left(K_{\mathrm{d}} \approx 0.12-0.5 \mathrm{nmol} \mathrm{1}^{-1}\right.$; Freemark and Comer, 1989; Pratt et al., 1991) to fetal liver microsomes, whereas ovine GH (oGH) or oPRL exhibits little to no specific binding to these membranes (Freemark et al., 1986). Saturation analyses of oPL binding sites in fetal liver (Pratt et al, 1991) indicate that the concentration of the binding site does not change with increasing gestational age (Table I), but the concentration does increase when the data are expressed per milligram of DNA, suggesting increased numbers of receptors per cell. Furthermore, saturation analyses using oPL, oGH or oPRL as the radiolabelled ligand (Pratt et al., 1991) and fetal liver microsomes demonstrated saturable binding with 


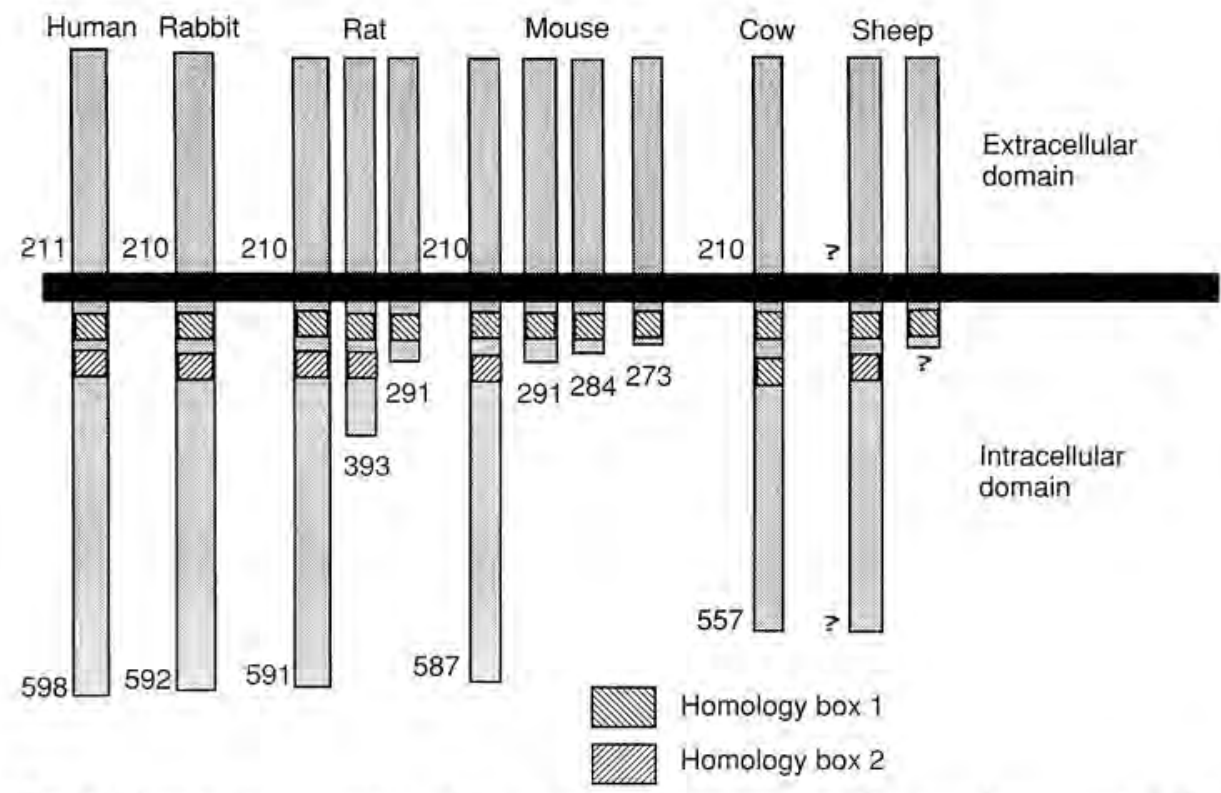

Fig. 4. Schematic representation of the various prolactin receptors that have been reported. The solid black bar represents the cellular membrane. Homology boxes $I$ and 2 are as described by DaSilva et al. (1994). The numbers presented above the solid black bar represent the number of amino acids in the extracellular domain of the receptors, and the numbers below the bar represent the total number of amino acids in the mature receptor protein. Note that the mouse, sheep and rat all have mRNA which encode a receptor that is truncated between Homology boxes 1 and 2 .

Table 1. Concentrations of ovine placental lactogen binding sites in fetal liver from mid- to late gestation

\begin{tabular}{lccc}
\hline $\begin{array}{l}\text { Gestational age } \\
\text { (days) }\end{array}$ & $\begin{array}{c}K_{\mathrm{d}} \\
\left(\mathrm{pmol} \mathrm{l}^{-1}\right)\end{array}$ & $\begin{array}{c}\text { fmol mg }^{-1} \\
\text { protein }\end{array}$ & $\begin{array}{c}\mathrm{fmol} \mathrm{mg}^{-1} \\
\text { DNA }\end{array}$ \\
\hline 60 & 120.0 & 14.0 & 14.4 \\
90 & 123.0 & 8.9 & 14.5 \\
105 & 148.0 & 9.6 & 21.0 \\
120 & 123.0 & 9.1 & 35.2 \\
135 & 96.5 & 7.4 & 37.5 \\
\hline
\end{tabular}

Data derived from Pratt et al. (1991).

oPL, but no specific binding of oGH or oPRL. Freemark and Comer (1989) reported the partial purification of the maternal and fetal liver oPL binding site. The apparent $M_{\mathrm{r}}$ of this receptor was $\approx 44000$, with a 30-50 times greater affinity for oPL than for oGH (Freemark and Comer, 1989), but no amino acid sequence information was reported.

Recent results from cross-linking and immunoprecipitation studies (Breier et al., 1994b) indicate that $\mathrm{OPL}$ and $\mathrm{OGH}$ can bind an identical or very similar receptor in fetal liver microsomes obtained at $125-135$ days of gestation. The amount of specific binding of oGH $(1,2 \pm 0.4 \%)$ is much less than that of oPL $(7.6 \pm 2.4 \%$ ), but the combination of these results led Breier et al. (1994b) to suggest that oGH and oPL bind to a common or a related receptor protein. This suggestion is corroborated by demonstrations that there is oGH receptor mRNA in fetal liver (Klempt ef al., 1993; Pratt and Anthony, 1993). However, when oGH receptor cDNA is expressed in $\mathrm{CHO}$ cells, GH exhibits greater affinity $\left(K_{\mathrm{d}}\right.$ 


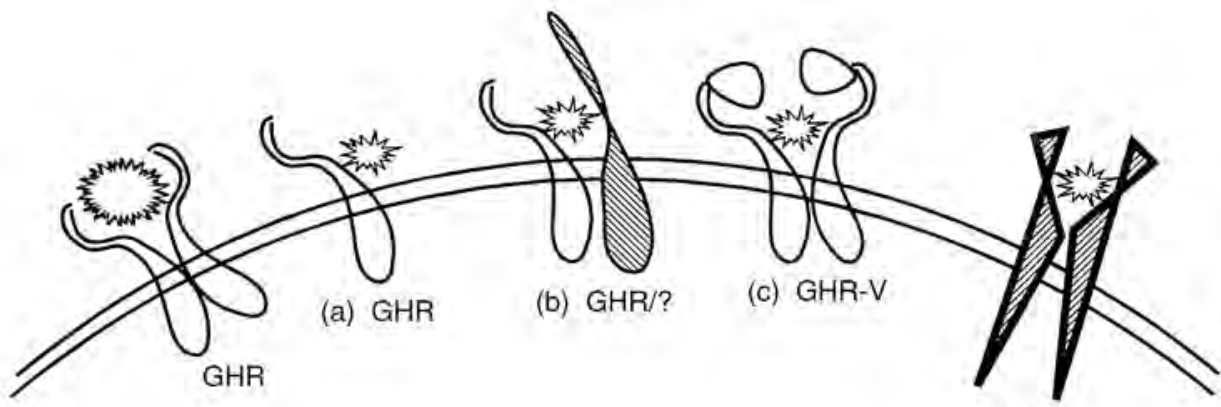

(d) PLR
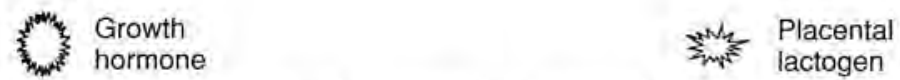

Fig. 5. Schematic representation of the possible identity of the ruminant placental lactogen (PL) receptor. (a) Ruminant PLs may act by binding to one monomer of the growth hormone receptor (GHR). (b) Ruminant PLs may act by binding to one monomer of the GHR and a yet undescribed monomer. (c) Ruminant PLs may act by binding to two monomers of a variant form of the GHR (GHR-V), such as a GHR with an amino-terminal extension. (d) Ruminant PLs may act through a receptor (PLR) that is structurally distinct from the GHR.

value $0.30 \mathrm{nmol}^{-1}$ ) for the oGH receptor than does oPL $\left(K_{\mathrm{d}}\right.$ value $0.76 \mathrm{nmol}^{-1}$ ), yet both ligands bind approximately the same number of oGH receptor molecules per cell (Fiddes et al., 1992). If the common receptor for oGH and oPL present in fetal liver (Breier ef al,, 1994b) is the oGH receptor, why does oGH not bind with equal or greater affinity than oPL. Furthermore, the sequence of the oGH receptor mRNA present during mid-gestation (day 60 to day 120 of gestation) in fetal liver differs within the $5^{\prime}$-untranslated region from the oGH receptor mRNA present at 135 days of gestation and in adult liver (Pratt and Anthony, 1993). The major oGH receptor mRNA transcript present during midgestation is about 300 base pairs larger than oGH receptor mRNA expressed in maternal liver (Pratt and Anthony, 1993). These results suggest that fetal liver oGH receptor mRNA is not derived from the recently described (O'Mahoney et al., 1994) exon IA of the $\mathrm{OGH}$ receptor gene. This implies a developmental switch in oGH receptor gene transcription, from usage of a variant-exon 1 to the adult liver-specific exon IA, during late gestation. The increase in oGH binding $(22.0 \pm 1.9 \%$; Breier et al., 1994a) that occurs in postnatal liver (18 days of age) does not occur in post-mature fetal liver (166-175 days of gestation; $1.7 \pm 0.29 \%$ ), further suggesting a periparturient switch in transcription and possibly the structure of the oGH receptor.

From the data available, firm conclusions cannot be drawn about the structure of the receptor for ruminant PLs. However, there are several possibilities about the identity of the PL receptor (Fig. 5). One possibility is that PL binds a single monomer of the GH receptor; another possibility is that it binds a single monomer of the $\mathrm{GH}$ receptor and a yet undescribed receptor monomer. It is possible that PL acts by binding a modified $\mathrm{GH}$ receptor, such as one that has an extended amino terminus, that through conformational changes loses its affinity for GH but retains its affinity for PL (Fig. 5). Finally, there may be a structurally distinct receptor for ruminant PLs. The structural characterization of the PL receptor may finally be accomplished using expression-cloning methods.

\section{Function of Ruminant Placental Lactogens}

Although the existence of ruminant PLs has been known for some time, their specific biological function(s) is not known. This is due to two factors, the first and more important is that classical ablation-replacement experiments are not feasible with placental hormones. This situation may be rectified in the future if ruminant embryonic stem cell lines become available to allow gene ablation 
experiments to be conducted. The second factor is the lack of highly purified biologically active ruminant PLs for functional studies. However, recombinantly derived bPL and OPL are now being used to determine their biological functions. Consequently, a more thorough understanding of the biological functions of these placental hormones should be forthcoming.

\section{Mammotrophic actions}

As their name implies, ruminant PLs may act on the mammary gland. Induction of mammogenesis in nonpregnant ewes is inhibited if prolactin secretion is prevented by administration of bromocryptine (Schams et al., 1984), but in pregnant sheep, mammary development occurs in the absence of prolactin secretion, suggesting the presence of a conceptus-derived mammotrophic agent (Schams et al., 1984). However, oPL is not as efficient as prolactin in stimulating $\beta$-casein mRNA transcription in ewe mammary gland explants (Serverly et al., 1983), and does not compete for prolactin binding sites in mammary tissue (Emane et al, 1986). The latter data were interpreted to suggest that oPL does not play an important role in mammogenesis and lactation. It is possible that the conceptus-derived mammotrophic agent (Schams et al, 1984) is not PL but a prolactin-related protein, although there is no evidence to support this hypothesis.

In cattle, as in sheep, inhibition of prolactin secretion during pregnancy does not impede mammary development (Schams et al., 1984). However, in contrast to sheep, bPL can bind the bPRL receptor with high affinity (Scott et al., 1992). Furthermore, bPL stimulates DNA synthesis in bovine mammary gland explants maintained in athymic nude mice (Vega et al., 1989). Recent evidence (Byatt et al., 1994) demonstrated the ability of bPLs to stimulate mammary growth and DNA synthesis. Bovine prolactin also stimulated mammary growth but did not significantly increase DNA synthesis. Both hormones induced milk synthesis, although prolactin was more potent than bPL, and bPL stimulated greater mammary secretion of the insulin-like growth factor binding proteins (IGFBP-2 and -3) than did prolactin (Byatt ef al., 1994). These data suggest that bPL may stimulate mammogenesis and lactation.

\section{Luteotrophic actions}

Several lines of evidence support the hypothesis that rodent PLs or prolactin-related proteins play a luteotrophic role during pregnancy. However, evidence for a similar role for ruminant PLs is lacking. Ovarian infusion with oPL does not increase progesterone secretion (Schramm et al, 1984) and short-term immunoneutralization of oPL does not alter progesterone concentrations in pregnant ewes (Waters et al., 1985). Furthermore, oPL does not appear capable of inhibiting the luteolytic actions of $\mathrm{PGF}_{2 a}$ (Schramm et al, 1984). These data shed doubt on any proposed action of oPL as a luteotrophin. However, recent evidence in cattle (Lucy et al., 1994) indicates that bPL injections will increase luteal size and plasma concentrations of progesterone, and reduce the size of the largest follicle. Some, but not all, of these effects were obtained with bGH injections. (Lucy et al., 1994). It is not yet clear whether the bGH receptors present in bovine luteal tissue (Lucy et al,, 1993) are functional receptors capable of mediating these actions, or whether the larger bGH receptor transcript is encoding a receptor responsible for these actions. Until more is known about the structure and function of bPL-binding sites in corpora lutea, firm conclusions cannot be drawn about the role of $\mathrm{bPL}$ as a luteotrophic hormone.

\section{Maternal and fetal metabolism}

Efforts to define the effects of PLs on maternal and fetal metabolism have focused primarily on the effects of human PL and $\mathrm{PL}$, but much of the available information was obtained using interspecific assays. Figure 6 shows the possible role of oPL in repartitioning maternal nutrients to the fetus and how oPL stimulates the fetus to use these substrates. However, as will be discussed, there is insufficient data to support or refate many of the hypotheses about the role of PL during pregnancy.

Infusion of partially purified oPL for $8 \mathrm{~h}$ to fasting pregnant and nonpregnant ewes decreased plasma concentrations of non-esterified fatty acids, glucose and amino nitrogen, but an increase in plasma insulin 


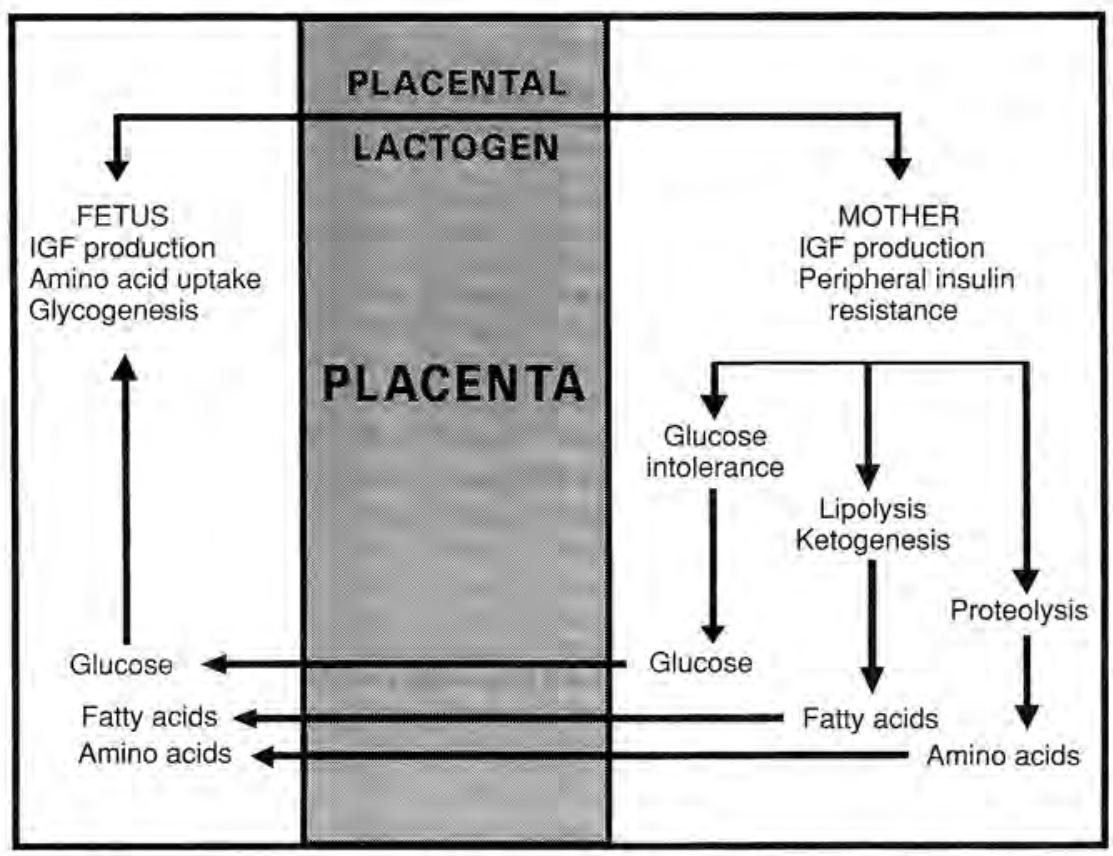

Fig. 6. Schematic representation of the hypothesis that ruminant placental lactogens (PLs) may act to repartition nutrients from the maternal system to the fetus. Redrawn from Handwerger (1991).

was observed (Handwerger et al., 1976). In contrast, infusion of a placental extract, enriched for oPL, for $36 \mathrm{~h}$ into nonpregnant ewes resulted in increased plasma non-esterified fatty acids, glucose and urea nitrogen, with no effect on plasma insulin (Thordarson et al, 1987). In addition, short-term (12 h) immunoneutralization of maternal oPL did not significantly affect whole body glucose metabolism, but there was a trend for lower plasma non-esterified fatty acids and a significant increase in plasma insulin (Waters et al., 1985). It is difficult to reach any firm conclusions from the results of these three reports as the experimental approach differed, especially in regard to dose and purity of oPL, pregnancy status and gestational age. Further research is required to determine the effects of oPL on maternal metabolism. The nutritional status of the ewes must be normalized across experiments, as fasting will increase oPL concentrations in both maternal and fetal circulation (Brinsmead et al., 1981), and reduce the concentration of oPL binding sites in matemal and fetal liver (Freemark et al., 1992). The latter effect of fasting can be reversed by glucose infusion (Freemark et al., 1992), suggesting not only nutritional regulation of oPL secretion but also of its function.

In cattle, administration of bPL to pregnant or nonpregnant, non-lactating cows did not increase concentrations of non-esterified fatty acids, glucose, tri-iodothyronine and insulin in plasma, whereas administration of bGH increased all of these parameters (Byatt et al., 1992). However, bGH and bPL increased plasma concentrations of IGF-I and IGF-II, and decreased the concentrations of blood urea nitrogen and IGFBP-2. Lucy et al. (1994) also noted an increase in circulating IGF-I when nonpregnant heifers were injected with bPL. These data from cattle are in contrast to at least some of the data available for sheep (see above), and the reasons for these differences are not known. However, Byatt et al. (1992) concluded that bPL was not necessarily acting as a GH agonist, but rather bPL elicited distinct effects on intermediary metabolism that may be mediated through another specific receptor.

If the role of PL is to repartition nutrients for fetal use (Fig. 6), catabolic actions within the maternal system should be offset by anabolic actions within the fetus. Ovine PL stimulates ornithine decarboxylase activity, amino acid uptake, IGF-II secretion and glycogen synthesis by fetal rat tissues (reviewed by Handwerger, 1991). Analogous treatment with GH is without effect. However, 
Table 2. Concentrations of ovine placental lactogen (OPL), insulin-like growth factor I (IGF-1) and insulin-like growth factor binding protein 2 (IGFBP-2) as a function of oPL infusion into fetal sheep vasculature

\begin{tabular}{lccc}
\hline & $\begin{array}{c}\text { Pre-infusion } \\
\left(\mathrm{ng} \mathrm{ml}^{-1}\right)\end{array}$ & $\begin{array}{c}\text { Saline infusion } \\
\left(\mathrm{ng} \mathrm{ml} \mathrm{ml}^{-1}\right)\end{array}$ & $\begin{array}{c}\text { oPL infusion } \\
\left(\mathrm{ng} \mathrm{ml}^{-1}\right)\end{array}$ \\
\hline oPL & $48.5 \pm 6.8$ & $\mathrm{na}$ & $186.3 \pm 28.1$ \\
IGF-1 & $34.8 \pm 3.2$ & $31.9 \pm 4.1$ & $\mathrm{na}$ \\
IGF-I & $30.3 \pm 5.7$ & $\mathrm{na}$ & $43.1 \pm 1.7$ \\
IGFBP-2 & $1271 \pm 80$ & na & na \\
IGFBP-2 & $1401 \pm 109$ & $1266 \pm 63$ \\
\hline
\end{tabular}

Data derived from Schoknecht et al. (1992b),

na: not available.

interpretation of these results must be tempered by the realization that oPL is not acting through oPL-specific receptors in these tissues. At least one of these actions occurs in fetal sheep tissues. Treatment of ovine fetal hepatocytes with oPL stimulated dose-dependent increases of glucose incorporation into glycogen and total cellular glycogen content (Freemark and Handwerger, 1986). Both $\mathrm{OGH}$ and $\mathrm{OPRL}$ stimulated glycogen synthesis by fetal hepatocytes, but their potencies were considerably less than that of oPL (12\% and $4 \%$ of oPLs potency, respectively). In addition, infusion of oPL at a rate of $1.2 \mathrm{mg}^{-1 a y}{ }^{-1}$ for 14 days into fetal vasculature (days 122-135 of pregnancy) increased fetal serum IGF-I concentrations, but did not affect serum IGFBP-2 (Table 2; Schoknecht et al., 1992b). Although these last results are not conclusive, they support the hypothesis that oPL may directly or indirectly stimulate IGF production by the fetus, thereby providing anabolic stimulation to the fetus.

The hypothesis shown in Fig. 6 is neither conclusively supported or refuted by the available data. It is clear that ruminant PLs can bind the GH receptor, and it is plausible that the role of PL in the maternal circulation is to augment or modulate the actions of GH within the mother. This may be accomplished by mediating its action through the GH receptor rather than by a structurally distinct receptor, However, some of the actions of GH (for example diabetogenic actions) may not be advantageous to the fetus, and actions of PL through a structurally distinct receptor may provide a more generalized anabolic fetal environment. Future research on the biological function of ruminant PLs must take into account that during pregnancy there are two separate metabolic units (mother versus fetus).

\section{Conclusions}

Placental members of the $\mathrm{GH} /$ prolactin gene family are true placental hormones that are not synthesized or secreted by other endocrine glands. In ruminants, these include the PLs and prolactin-related proteins. Considerable progress has been made in defining the primary structure and gene organization of these placental hormones. However, we do not know what specifically regulates production of these hormones, their mechanism of action or their specific biological functions. This is particularly true for the family of ruminant prolactin-related proteins. Ruminant PLs may act through receptors other than GH or prolactin receptors, but this remains controversial and will be resolved only when specific PL binding sites are structurally characterized. Methods are now available to incorporate a functional binding assay into the search for PL receptors, and these methods should be used for both maternal and fetal tissues. Finally, there is a need to define the function(s) of this placental gene family. These research efforts must take into consideration the pregnancy status, gestational age and nutritional status of the experimental animals. With the availability of recombinantly derived hormones, and availability of gene ablation on the horizon, the function of this placental gene family may finally be resolved. 


\section{References}

Anthony RV, Smith GW, Duong A, Pratt SL and Smith MF (1994) Identification of two forms of prolactin receptor mRNA in ovine fetal liver and adult ovary Biology of Reproduction $\mathbf{5 0}$ (Supplement I) 120 (Abstract)

Beckers JF, deCoster R, Wouters-Ballman P, Fromont-Lienard C, van der Zwalman $\mathrm{P}$ and Ectors $\mathrm{F}$ (1982) Dosage radioimmunologique de l'hormone placentaire somatotrope et mammotrope bovine Annales Medecine Veterinaire 126 9-21

Boutin J-M, Jolicoeur C, Okamura H, Gagnon J, Edery M, Shirota M, Banville D, Dusanter-Fourt Is Diiane J and Kelly PA (1988) Cloning and expression of the rat prolactin receptor, a member of the growth hormone/prolactin receptor gene family Cell $\mathbf{5 3}$ 69-77

Breier BH, Ambler GR. Sauerwein H, Surus A and Gluckman PD (1994a) The induction of hepatic somatotrophic receptors after birth in sheep is dependent on parturition-associated mechanisms Journal of Endocrinology 141 101-108

Breier BH, Funk B, Surus A, Ambler GR, Wells CA, Waters MJ and Gluckman PD (1994b) Characterization of ovine growth hormone $(\mathrm{OGH})$ and ovine placental lactogen (oPL) binding to fetal and adult hepatic tissue in sheep: evidence that $\mathrm{oGH}$ and $\mathrm{OPL}$ interact with a common receptor Endocrinology 135 919-928

Brinsmead MW, Bancroft B], Thorburn GD and Waters MJ (1981) Fetal and maternal ovine placental lactogen during hyper. glycaemia. hypoglycaemia and fasting Joumal of Endocrinology $90337-343$

Byatt JC, Welply JK, Leimgruber RM and Collier RJ (1990) Characterization of glycosylated bovine placental lactogen and the effect of enzymatic deglycosylation on receptor binding and biological activity Endocrinology 127 $1041-1049$

Byatt JC, Eppard PJ, Veenhuizen J, Sorbet RH, Buonomo FC, Curran DF and Collier RJ (1992) Serum half-life and in vivo actions of recombinant bovine placental lactogen in the dairy cow Joumal of Endocrinology 132 185-193

Byatt JC, Eppard PJ, Veenhuizen JJ, Curran TL, Curran DF, McGrath MF and Collier RJ (1994) Stimulation of mammogenesis and lactogenesis by recombinant bovine placental lactogen in steroid-primed dairy hejfers Journal of Endocrinology $140 \quad 33-43$

Currie WB, Card CE, Michel FJ and Ignotz G (1990) Purification, partial characterization, and development of a specific radioimmunoassay for goat placental lactogen Journal of Reproduction and Fertility $90 \quad 25-36$

DaSilva L, Howard OMZ, Rui H, Kirken RA and Farrar WL (1994) Growth signaling and JAK2 association mediated by membrane-proximal cytoplasmic regions of prolactin receptor Journal of Biological Chemistry $26918267-18270$

Davis JA and Linzer DIH (1989) Expression of multiple forms of the prolactin receptor in mouse liver Molecular Endocrinol. ogy 3 674-680

Dietz AB, Georges M, Threadgill DW, Womack JE and Schuler LA (1992) Somatic cell mapping, polymorphism, and linkage analysis of bovine prolactin-related proteins and placental lactogen Genomics 14 137-143

Ebbitt DM, Hurley WL, Kessler MA, MCDonald DJ and Schuler LA (1989) Characterization of the gene corresponding to bovine placental prolactin-related cDNA. I. Evolutionary implications DNA \& 161-169
Emane MN, Delouis C, Kelly PA and Diiane J (1986) Evolution of prolactin and placental lactogen receptors in ewes during pregnancy and lactation Endocrinology 118 695-700

Fiddes RJ, Brandon MR and Adams TE (1992) Functional expression of an ovine growth hormone receptor in transfected Chinese hamster ovary cells Molecular and Cellular Endocrinology $86 \quad 37-47$

Freemark M and Comer M (1989) Purification of a distinct placental lactogen receptor, a new member of the growth hormone/prolactin receptor family Journal of Clinical Investigation $83 \quad 883-889$

Freemark M and Handwerger S (1986) The glycogenic effects of placental lactogen and growth hormone in ovine fetal liver are mediated through binding tô specific fetal ovine placental lactogen receptors Endocrinology 118 613-618

Freemark M, Comer M and Handwerger S (1956) Placental lactogen and GH receptors in sheep liver: striking differences in ontogeny and function American joumal of Physiology 251 E328-E333

Freemark M, Keen A, Fowlkes J, Mularoni T, Comer M, Grandis A and Kodack L (1992) The placental lactogen receptor in maternal and fetal sheep liver: regulation by glucose and role in the pathogenesis of fasting during pregnancy Endocrinology $1301063-1070$

Handwerger S (1991) Clinical counterpoint: the physiology of placental lactogen in human pregnancy Endocrine Reoietos $12329-336$

Handwerger S, Fellows RE, Crenshaw MC, Hurley T, Barrett J and Maurer WE (1976) Ovine placental lactogen: acute effects on intermediary metabolism in pregnant and non-pregnant sheep Journat of Endocrinology 69 133-137

Kappes SM, Warren WC, Pratt SL., Liang R and Anthony RV (1992) Quantification and cellular localization of ovine placental lactogen messenger ribonucleic acid expression during mid- and late gestation Endocrinology 131 2829-2838

Kessler MA and Schuler LA (1991) Structure of the bovine placental lactogen gene and alternative splicing of transcripts DNA and Cell Biology 10 93-104

Kessler MA, Duello TM and Schuler LA (1991) Expression of prolactin-related hormones in the early bovine conceptus, and potential for paracrine effects on the endometrium Endocrinology 129 1885-1895

Klempt M, Bingham B, Breier BH, Baumbach WR and Gluckman PD (1993) Tissue distribution and ontogeny of growth hormone receptor messenger ribonucleic acid and ligand binding to hepatic tissue in the midgestation sheep fetus Endocrinology 132 1071-1077

Liang R and Anthony RV (1993) Characterization of the gene encoding ovine placental lactogen Biology of Reproduction 48 (Supplement 1) 177 (Abstract)

Lucy MC, Collier RJ, Kitchell MI, Dibner J, Hauser SD and Krivi GG (1993) Immunohistochemical and nucleic acid analysis of somatotropin receptor populations in the bovine ovary Biology of Reproduction 48 1219-1227

Lucy MC, Byatt JC, Curran TL, Curran DF and Collier RJ (1994) Placental lactogen and somatotropin hormone binding to the corpus luteum and effects on the growth and functions of the ovary in heifers Biology of Reproduction $\mathbf{5 0}$ $1136-1144$ 
Milosavljevic M, Duello TM and Schuler LA (1989) In sifu localization of two prolactin-related messenger ribonucleic acids to binucleate cells of bovine placentomes Endocrinology $125883-889$

Murthy GS, Schellenberg $C$ and Friesen HG (1982) Purification and characterization of bovine placental lactogen Endocri. nology $1112117-2124$

Nie Z-R and Chan JSD (1990) Concomitant measurement of ovine placental lactogen, pituitary growth hormone and prolactin in maternal and fetal plasma of a pregnant ewe carrying an anencephalic fetus: a case report Animal Reproduction Science 22 213-220

O'Mahoney JV, Brandon MR and Adams TE (1994) Identification of a liver-specific promoter for the ovine growth hormone receptor Molecular and Cellular Endocrinology 101 129-139

Pratt SL and Anthony RV (1993) Ovine fetal liver expresses a variant form of the growth hormone receptor messenger ribonucleic acid The Endocrine Society 75th Annual Meeting and Abstracts, Abstract 263

Pratt SL, Kappes SM and Warren WC (1991) Fetal liver ovine placental lactogen receptor concentrations from day 60 to 135 of gestation Biology of Reproduction 44 (Supplement 1) 168 (Abstract)

Roberts RM and Anthony RV (1994) Molecular biology of trophectoderm and placental hormones. In Molecular Bialogy of the Female Reproductive System pp 395-440 Ed. JK Findlay. Academic Press, San Diego, CA

Rueda BR, Dunn TG, Anthony RV and Moss GE (1994) Influence of fetal death and fetectomy on gestation and the initiation of parturition in the ewe Journal of Developmental Physiology 20 159-164

Schams D, Russe I, Schallenberger E, Prokopp S and Chan JSD (1984) The role of steroid hormones, prolactin and placental lactogen on mammary gland development in ewes and heifers Joumal of Endocrinology 102 121-130

Schoknecht PA, Currie WB and Bell AW (1992a) Kinetics of placental lactogen in mid-and late-gestation ovine fetuses Joumal of Endocrinology 133 95-100

Schoknecht PA, McGuire MA, Cohick WS, Currie WB and Bell AW (1992b) The effect of placental lactogen infusion on serum IGF-I and IGFBP-2 concentrations in the late gestation ovine fetus Journal of Anmal Science $\mathbf{7 0}$ (Supplement 1) 212 (Abstract)

Schramm W, Friesen HG, Robertson HA and McCracken JA (1984) Effect of exogenous ovine placental lactogen on luteolysis induced by prostaglandin F-2 $\alpha$ in sheep Journal of Reproduction and Fertility 70 557-565

Schuler LA, Shimomura K, Kessler MA, Zieler CG and Bremel RD (1988) Bovine placental lactogen; molecular cloning and protein structure Biochemistry 27 8443-8448

Schuler LA, Kessler MA, Tanaka M and Nakashima K (1991) Nomendature darification for the bovine placental prolactin-related hormones Endocrinology 1262057

Scott P, Kessler MA and Schuler LA (1992) Molecular cloning of the bovine prolactin receptor and distribution of prolactin and growth homone receptor transcripts in fetal and utero-placental tissues Molecular and Cellular Endocrinology $8947-58$
Serverly J-L, Emane NM, Houdebine L-M, Djiane J, Delouis C and Kelly PA (1983) Comparative measurement of the lactogenic activity of ovine placental lactogen in rabbit and ewe mammary gland General and Comparative Endocrinology 51 $255-262$

Staten NR, Byatt JC and Krivi GG (1993) Ligand-specific dimerization of the extracellular domain of the bovine growth hormone receptor Journal of Biological Chemistry $26818467-18473$

Taylor MJ, McMillen IC, Jenkin G, Robinson IS and Thorburn GD (1983) The regulation of ovine placental lactogen: the role of the fetal hypothalamic-pituitary axis Journal of Developmental Pliysiology 5 251-258

Thordarson G, McDowell GH, Smith SV, Iley S and Forsyth IA (1987) Effects of continuous intravenous infusion of an ovine placental extract enriched in placental lactogen on plasma hormones, metabolites and metabolic biokinetics in non-pregnant sheep Journal of Endocrinology 113 277-283

Vega JR, Sheffield LG and Bremel RD (1989) Bovine placental lactogen stimulates. DNA synthesis of bovine mammary tissue maintained in athymic nude mice Proceedings of the Society for Experimental Biology and Medicine 192 135-139

Wallace CR (1993) Concentrations of bovine placental lactogen in dairy and beef cows across gestation Domestic Animal Endocrinology 10 67-70

Wallis M (1993) Remarkably high rate of molecular evolution of ruminant placental lactogens journal of Molecular Evolution $3786-88$

Warren WC, Keisler DH and Anthony RV (1990a) Synthesis and secretion of ovine placental lactogen and its biochemical properties Domestic Animal Endocrinology 7 331-342

Warren WC, Liang R, Krivi GG, Siegel NR and Anthony RV (1990b) Purification and structural characterization of ovine placental lactogen Joumal of Endocrinology 126 141-149

Waters MJ, Oddy VH, McCloghry CE, Gluckman PD, Duplock R, Owens PC and Brinsmead MW (1985) An examination of the proposed roles of placental lactogen in the ewe by means of antibody neutralization Journal of Endocrinology $106377-386$

Wintour EM, Hardy KJ, Hennessy DP, Friesen HG, Klindt J and Worsley I (1982) The effect of bilateral fetal adrenalectomy on the concentration of ovine placental lactogen in pregnant ewe plasma Joumal of Developmental Physiology $\mathbf{4}$ 273-278

Wooding FBP (1982) The role of the binucleate cell in ruminant placental structure Journal of Reproduction and Fertility Supplement 31 31-39

Wooding FBP (1992) Current topic: the synepitheliochorial placenta of ruminants: binucleate cell fusions and hormone production Placenta 13 101-113

Yamakawa M, Tanaka M, Koyama M, Kagesto Y, Watahiki M, Yamamoto M and Makashima K (1990) Expression of new members of the prolactin growth hormone gene family in bovine placenta Joumal of Biological Chemistry 265 $8915-8920$

Zieler CG, Kessler MA and Schuler LA (1990) Characterization of a novel prolactin-related protein from bovine fetal placenta Endocrinology $126 \quad 2372-2382$ 